Sherry units. The largest amount of plasminogen likely to be added in any cerebrospinal fluid will be very small compared with this change and can therefore be ignored. A concentration of 1 Sherry unit of plasminogen in the system appears to be suitable.

Figure 2 shows the effect of varying the streptokinase concentration over a wide range while keeping plasminogen constant. It will be seen that if a concentration of 0.5 units of streptokinase is used this will give a convenient lysis time of about $20 \mathrm{~min}$., while permitting a large increase of lysis time with small reductions in streptokinase. A small amount of added plasminogen therefore produces no change in lysis time, while a small inhibitory effect on the streptokinase will produce a large change.

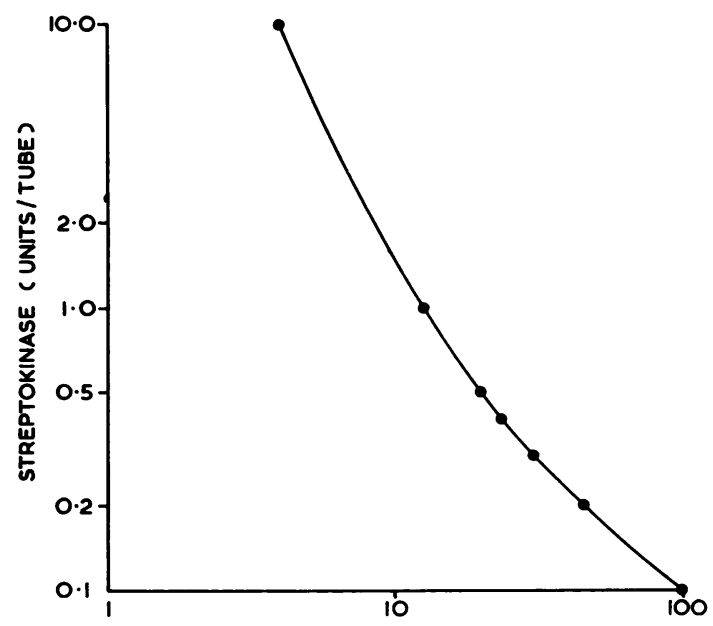

FIG. 2.

LYSIS TIME (min.)

The reagents used are as follows:

Bovine fibrinogen (Armour). $0.8 \%$ in phosphate buffer Phosphate buffer ............... M/15 pH 7.4 Purified human plasminogen. . . 10 sherry units $/ \mathrm{ml}$. in $0.85 \%$ saline

Streptokinase (Wellcome) . . . . . . . u. $/ \mathrm{ml}$. in water Thrombin (Parke-Davis) .......50 u./ml. in saline The test is carried out in 5 in. $\times \frac{1}{2}$ in. test tubes and the reagents are used in the following quantities:

Fibrinogen ...............

Buffer $\ldots \ldots \ldots \ldots \ldots \ldots \ldots \ldots \ldots \ldots \ldots 1 \mathrm{ml}$.

Plasminogen $\ldots \ldots \ldots \ldots \ldots \ldots \ldots \ldots .1 \mathrm{ml}$.

Cerebrospinal fluid $\ldots \ldots \ldots \ldots \ldots .1 \mathrm{ml}$.

Streptokinase $\ldots \ldots \ldots \ldots \ldots \ldots \ldots \ldots .1 \mathrm{ml}$.

Thrombin .................

The tubes are placed in a transparent water-bath at $37^{\circ} \mathrm{C}$. as soon as the clots have formed and the lysis times are read visually or by means of a photoelectric instrument (Newman, 1964). Inhibition of streptokinase can then be estimated from a standard curve (Fig. 2). Lysis times are normally about 20 minutes, but a control tube without cerebrospinal fluid should always be included as the plasminogen loses potency slightly after several hours at room temperature.

\section{A model of human karyotype for teaching}

\section{R. G. CHITHAM From the Department of Pathology, Queen Mary's Hospital for Children, Carshalton, and the Medical Research Council Laboratories, Carshalton}

Lecturing on human chromosomes using the standard aids of blackboard and slides presents several difficulties. The slide, though admirable for magnifying real chromosomes, demonstrates one defect at a time. The blackboard is unsatisfactory for illustrating the whole karyotype and, if gamete formation or translocation are being shown, constant rubbing out and redrawing are necessary. It was therefore decided to produce a background on which could be placed chromosome models illustrating the whole Denver system.

The background on which the chromosomes are mounted is a board 18 inches by 28 inches covered on both sides by a white plastic material. The chromosomes are cut from a sheet of black plastic. The cost of the board and plastic sheet is $22 \mathrm{~s} 6 \mathrm{~d}$. and may be purchased under the trade name Cellograph ${ }^{1}$. It is normally sold for making visual aids for teaching children.

To obtain the outlines of chromosomes, a slide of the Denver system of chromosome arrangement is projected on to the plastic. A tracing is then made and the chromosomes cut out. They can then be arranged as required anywhere on the board and are easily detached and replaced as long as the board is kept clean. The set is now being used for teaching purposes.

Miller, Hyde, and Selden (1963) advocated the use of a felt board and chromosomes. For our purposes, however, it was decided that a plastic teaching set had advantages which were: (1) a rigid board which could be stood up or hung as desired; (2) it provides a background which can be drawn on with a felt pencil, especially useful when

${ }^{1}$ Messrs. Philip and Tacey Ltd., 69-79, Fulham High Street, London, S.W.6.

Received for publication 1 May 1964.

Method for the detection and measurement of antibodies to streptokinase in cerebrospinal fluid-continued.

I am grateful to Dr. M. McKay of the Lister Institute for generous supplies of plasminogen and to Dr. G. T. Stewart of this Department for helpful advice.

\section{REFERENCES}

Newman, R. L. (1964). J. clin. Path., 17, 194. Stewart, G. T. (1964). Ibid., 17, 355. 


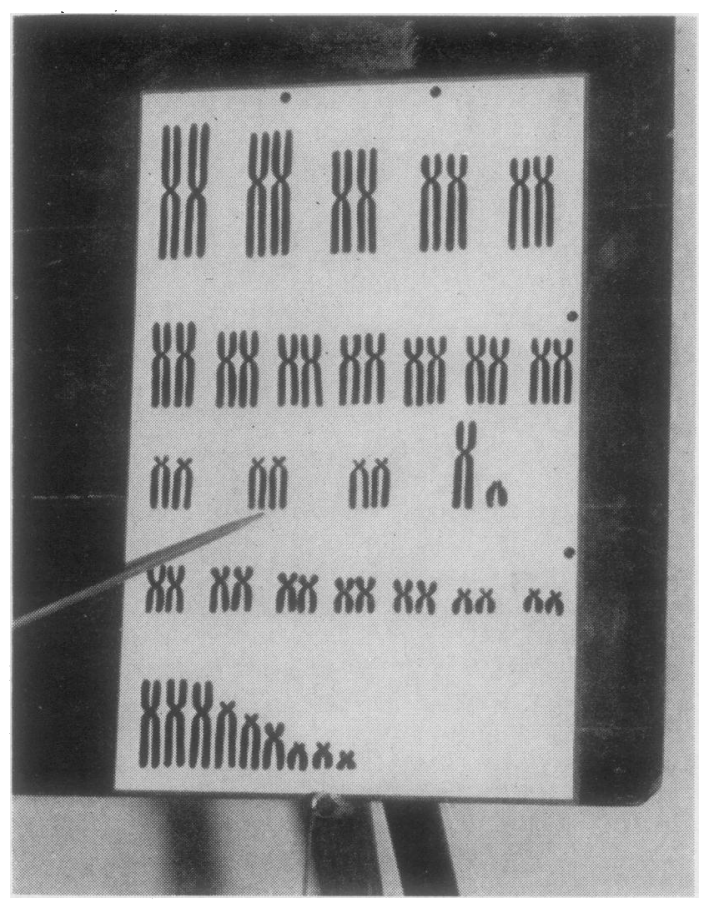

FIG. 1. The plastic teaching set shown in position on the board.

demonstrating gamete formation and non-disjunction; (3) a neater appearance and greater durability.

The result is shown in the photograph. The chromosome models can be moved from place to place or may be joined to each other to illustrate translocation. The bottom line of chromosomes allows construction of karyotypes in which extra or abnormal chromosomes are present.

\section{REFERENCE}

Miller, J. Q., Hyde, Margaret S., and Selden, Robert F. Jr. (1963) Lancet, 2, 155: A useful teaching device.

\section{Book reviews}

THE Bacterial CEll Wall By Milton R. J. Salton. (Pp. xiii + 293; 77 figures. 80s.) Amsterdam, London and New York: Elsevier Publishing Co. 1964.

The cell wall is the part of the anatomy of bacteria that is of greatest interest to the pathologist. It is essential for the continued life of the bacterium under natural conditions, since it contains and supports the protoplast which would otherwise explode because of its high internal osmotic pressure. Being exposed at the surface of the bacterium, except when covered by a capsule or microcapsule, the cell wall is vulnerable to attack by a variety of antibacterial agents; it is, for instance, the target of action of lysozyme and other bacteriolytic enzymes, and of penicillin and certain other antibiotics. In many bacterial species it contains the specific receptors for infecting bacteriophages, the type-specific O-antigens, the endotoxins, pyrogens, and hypersensitivity-inducing agents.

During the last 15 years, largely as a result of developments in electron microscopy and biochemistry, a vast amount of new information has been obtained about the structure, function, chemical composition, biosynthesis, and pathology of the bacterial wall, and this information is ably and lucidly reviewed in this book by Professor Salton.

The introductory chapter discusses the relations of the wall to the other structures of the bacterial cell and distinguishes the different compositions of the surface coverings in four groups of organisms. Mycoplasma and Halobacterium have a single, non-rigid membrane; Gram-positive bacteria have a flexible plasma membrane and a thick, rigid, apparently amorphous, outer cell wall; Gram-negative bacteria have two multilayered membranes, the inner of which may be a plasma membrane, and the outer the rigid cell wall; Lampropedia and certain cocci have highly complex coverings. This chapter, and a subsequent one describing the electron microscopy and macromolecular architecture of isolated walls, are both illustrated by reproductions of many fine electron micrographs. An interesting and readable account is given of the technical methods used for isolating and purifying preparations of bacterial walls, and then three chapters deal with the chemical composition of the walls, emphasizing the differences between Gram-positive and Gram-negative bacteria, with the structure of the mucopeptide, or 'glycosaminopeptide', component that is present in the walls of almost all bacteria and is responsible for their rigidity, and with the occurrence and structure of the teichoic acids. A chapter on cell-wall antigens and bacteriophage receptors includes a discussion of the relationship of chemical structure to antigenic specificity in the lipopolysaccharides (Oantigens) of Gram-negative bacilli, and the important role of the teichoic acids as antigens in staphylococci and streptococci. A final chapter on the biosynthesis of bacterial cell walls deals with the biochemistry of the synthesis of the different wall components, with the 